\title{
KOHORT EVALUASI NYAMUK DEWASA SETELAH PELAKSANAAN FOGGING FOCUS DI DESA SIDAMULIH KECAMATAN RAWALO KABUPATEN BANYUMAS TAHUN 2016
}

\author{
Irawan Endy Pratama', Aris Santjaka'), Arif Widyanto ${ }^{3)}$ \\ Jurusan Kesehatan Lingkungan, Politeknik Kesehatan Kemenkes Semarang, \\ Jl. Raya Baturaden KM 12 Purwokerto, Indonesia
}

\begin{abstract}
Abstrak
Latar Belakang fogging focus dilaksanakan di daerah yang ada kasus Demam Berdarah Dengue dengan bertujuan untuk menekan secara cepat densitas nyamuk dewasa sehingga Kejadian Luar Biasa dapat dicegah. Desa Sidamulih terdapat 2 kasus DBD serta tambahan 12 kasus penderita panas dalam 3 minggu. Tujuan penelitian mengetahui densitas nyamuk dewasa sebelum dan setelah pelaksanaan fogging focus sebagai parameter langsung. Jenis penelitian observasional dengan pendekatan kohort. Hasil penelitian menunjukan dengan analisis uji Anova LSD mengetahui densitas nyamuk dari dampak fogging focus. Hasil uji lanjut ternyata densitas nyamuk hari ke 3 setelah fogging focus I tidak ada beda dengan sebelum fogging focus I $(p 0,474)$ dan hari ke 10 setelah fogging focus II tidak ada beda dengan sebelum fogging focus I $(p 0,144)$. Disimpulkan fogging focus hanya efektif setelah 3 hari pada siklus fogging focus ke II. Disarankan fogging focus bukan satu-satunya cara untuk menekan densitas nyamuk.
\end{abstract}

Kata kunci ： Nyamuk Dewasa ; Fogging focus

\begin{abstract}
[Cohort Evaluation Of Adult Mosquitoes After Fogging Focus Treatment In Sidamulih Village Subdistrict Rawalo Banyumas Regency Year 2016]. Background fogging focus carried out in areas that there are cases of Dengue Fever with an aim to reduce the adult mosquito density rapidly so that the extraordinary Events can be prevented. The village of Sidamulih there were 2 case of DBD and 12 additional cases sufferers of heat in 3 weeks. This research was aimed to knowing the density of mosquito adults before and after implementation of the fogging focus as a parameter directly. This research design was observasional with a cohort approach. The research results showed with the analysis of Anova test LSD knowing the density of mosquito fogging impact focus. Further test results turned out to be the density of mosquito fogging after 3 days into focus I no different from prior fogging focus I ( $p$. 0.474) and the 10th day after fogging focus II there is no different from prior fogging focus I ( $p$. 0.144). It is conclude fogging focus is only effective after 3 days on cycle fogging focus II. Recommended fogging focus isn't the only way to suppress mosquito density.
\end{abstract}

Keywords : Adult mosquitoe ; Fogging focus

\section{PENDAHULUAN}

Penyakit Demam Berdarah Dengue mudah di tularkan melalui gigitan nyamuk Aedes aegypti. Kelembaban udara yang cukup tinggi menjadi pemicu berkembang biaknya nyamuk Aedes aegypti. Hal tersebut menyebabkan masalah kesehatan karena banyak terdapat daerah endemik sehingga jumlah penderita semakin meningkat dan penyebaran pun semakin meluas ke wilayah lain. (Widoyono, 2008)

Demam Berdarah Dengue (DBD) merupakan suatu penyakit endemik di daerah tropis yang memiliki tingkat kematian tinggi terutama pada anak - anak. Indonesia merupakan negara dengan tingkat kejadian Demam Berdarah Dengue maupun Demam Dengue (DD) yang tinggi. Berdasarkan publikasi

1) Email : endypratama11@gmail.com

2) Email : arissantjaka@gmail.com

3) Email : arifwidyanto74@yahoo.com
Guidelines for Diagnosis, Treatment, Prevention and control, merupakan masalah kesehatan masyarakat yang besar di Indonesia. Sejak pertama kali ditemukan di Indonesia pada tahun 1968, angka kejadian Demam Berdarah Dengue di Indonesia terus meningkat. Dalam kurun waktu 5 tahun di indonesia selalu di temukan kasus Demam Berdarah Dengue. (Depkes, 2014)

Kasus Demam Berdarah Dengue di Kabupaten Banyumas sejak tahun 2014 sebanyak 209 kasus, meningkat menjadi 221 kasus pada tahun 2015. (Dinkes Banyumas, 2015)

Tujuan penelitian adalah untuk Mengetahui densitas nyamuk dewasa resting sebelum dan setelah pelaksanaan fogging focus ke dua di Desa Sidamulih 
Kecamatan Rawalo Kabupaten Banyumas pada tahun 2016.

\section{BAHAN DAN METODE}

Jenis penelitian adalah penelitian observasional dengan pendekatan kohort, yaitu mengikuti pergerakan densitas nyamuk dari sebelum dilakukan fogging focus pertama sampai densitas nyamuk setelah fogging focus kedua mendekati densitas nyamuk sebelum fogging focus pertama. Populasi adalah semua rumah yang berada pada Desa Sidamulih Kecamatan Rawalo Kabupaten Banyumas. Teknik pengambilan sampel menggunakan purposive sampling yaitu sampel diambil 2 rumah indeks kasus kemudian masingmasing di tarik garis lurus 200 meter ke arah utara, selatan, barat dan timur. Pengukuran densitas nyamuk menggunakan checklist observasi pelaksanaan fogging focus dan checklist observasi hasil penangkapan dan identifikasi densitas nyamuk. Hasil pengukuran dianalisis menggunakan soft ware analisis data yang terdiri dari analisis univariate untuk meringkas data hasil pengukuran dan analisis bivariate menggunakan uji Anova one way.

\section{HASIL DAN PEMBAHASAN}

\section{Univariate}

1. Hasil Pengukuran Intensitas Cahaya

Pengukuran di ambil rata-rata pengukuran 4 ruangan yaitu : Ruang tamu, Ruang kamar, Kamar mandi, Ruang dapur. Pengukuran pencahayaan sebelum pelaksanaan fogging focus I di dan pengukuran pencahayaan setelah pelaksanaan fogging focus II di lakukan pada pukul 07.30-12.30 WIB dengan menggunakan alat Lux meter. Dengan hasil rata-rata dari intensitas cahaya perumah dengan hasil antara 48-392 lux. Menurut Cecep Dani Sucipto (2011, h.50), bahwa nyamuk mempunyai kesukaan atau kebiasaan beristirahat di tempat yang gelap dan lembab.Nyamuk mempunyai kesukaan pada tempat redup dengan range 9-325,7 lux. dan hasil ratarata adalah 225,3 lux. membuktikan nyamuk suka pada tempat gelap dan redup sebagai tempat istirahat atau resting.(Arofati, dkk,2012).

\section{Hasil Pengukuran Suhu}

Pengukuran di ambil rata-rata pengukuran 4 ruangan yaitu : Ruang tamu, Ruang kamar, Kamar mandi, Ruang dapur. Pengukuran suhu sebelum pelaksanaan fogging focus I dan pengukuran suhu setelah pelaksanaan fogging focus II di lakukan pada pukul 07.30-12.30 WIB dengan menggunakan alat Hygrometer. Dengan hasil rata-rata antara $26-30^{\circ} \mathrm{C}$. Suhu optimum perkembangbiakan nyamuk antara $25^{\circ} \mathrm{C}-27^{\circ} \mathrm{C}$ dan akan terhenti sama sekali pada suhu $<10^{\circ} \mathrm{C}$ atau $>40^{\circ} \mathrm{C}$. (Depkes RI Ditjen PP dan PL,
2007, h.8) jadi, dari ratarata 34 rumah masih berada di suhu optimum perkembangbiakan nyamuk. yang memungkinkan bertambah banyaknya nyamuk.

3. Hasil Pengukuran Kelembaban

Pengukuran di ambil rata-rata pengukuran 4 ruangan yaitu : Ruang tamu, Ruang kamar, Kamar mandi, Ruang dapur. Pengukuran suhu sebelum pelaksanaan fogging focus I dan pengukuran suhu setelah pelaksanaan fogging focus II di lakukan pada pukul 07.30-12.30 WIB dengan menggunakan alat Hygrometer. pengukuran kelembaban didalam rumah dengan hasil rata-rata $60-86 \%$ kelembaban tertinggi pada rata-rata $86 \%$. Kebutuhan kelembaban yang tinggi mempengaruhi nyamuk untuk mencari tempat yang lembab dan basah sebagai tempat hinggap atau istirahat. Pada kelembaban kurang dari 60\% umur nyamuk menjadi pendek. (Depkes RI Ditjen PP \& PL, 2007, h.9)Hasil tersebut membuktikan nyamuk memilih tempat yang lembab dan basah $>60 \%$ sebagai tempat istirahat atau resting place.

4. Hasil Pengukuran Kecepatan Angin

Pengukuran kecepatan angin dilakukan pada pelaksanaan fogging focus I dan II. Pengukuran dilakukan secara berkala selama 3 kali pengukuran dengan alat anemometer di luar ruangan pada saat kegiatan fogging berlangsung yang diambil jumlah rata-rata dari tiga pengukuran yaitu fogging focus I $1,03 \mathrm{~m} / \mathrm{s}$ dan fogging focus II 4,36 m/s. Menurut DITJEN.PP \& PL, 2007a, h.8 Angin sangat mempengaruhi terbang nyamuk. Secara langsung angin akan mem-pengaruhi penguapan (evaporasi) air dan suhu udara (konveksi). Menurut WHO (2003) kecepatan angin pada saat fogging focus kondisi yang paling baik kecepatan angin tetap 3-13 km/ jam , kondisi rata-rata $0-3 \mathrm{~km} / \mathrm{jam}$ dan kondisi tidak baik $>13 \mathrm{~km} / \mathrm{jam}$. Hasil ini menunjukan kecepatan angin pada saat fogging focus I dan II dalam kondisi baik karena 3-13 km/jam.

5. Penangkapan Nyamuk Sebelum fogging focus I

\begin{tabular}{lccc}
\hline \multirow{2}{*}{$\begin{array}{c}\text { Jenis } \\
\text { Nyamuk }\end{array}$} & \multicolumn{3}{c}{ Sebelum Fogging focus I } \\
\cline { 2 - 4 } & $\begin{array}{c}\text { Jumlah } \\
\text { Semua } \\
\text { Nyamuk }\end{array}$ & $\begin{array}{c}\text { Jumlah } \\
\text { Nyamuk } \\
\text { (ekor) }\end{array}$ & \% \\
\hline Aedes aegypti & 57 & 0 & 0 \\
\hline Aedes albopictus & 57 & 7 & 12,28 \\
\hline Armigeres & 57 & 1 & 1,75 \\
\hline Anopheles sp & 57 & 0 & 0 \\
\hline Culex sp & 57 & 47 & 82,45 \\
\hline
\end{tabular}

Hasil pengukuran densitas nyamuk sebelum pelaksanaan fogging focus I Desa Sidamulih Kecamatan Rawalo Kabupaten Banyumas yaitu sebanyak 57 ekor nyamuk. 47 ekor nyamuk Culex sp dengan persentase 85\%, 7 ekor nyamuk 
Aedes albopictus dengan persentase 13\%, dan 1 ekor nyamuk Armigeres dengan persentase 2\% . persentase dari penangkapan nyamuk jenis Aedes aegypti 0\%, Anopheles sp 0\%.

6. Penangkapan Nyamuk 3 hari Setelah fogging focus I

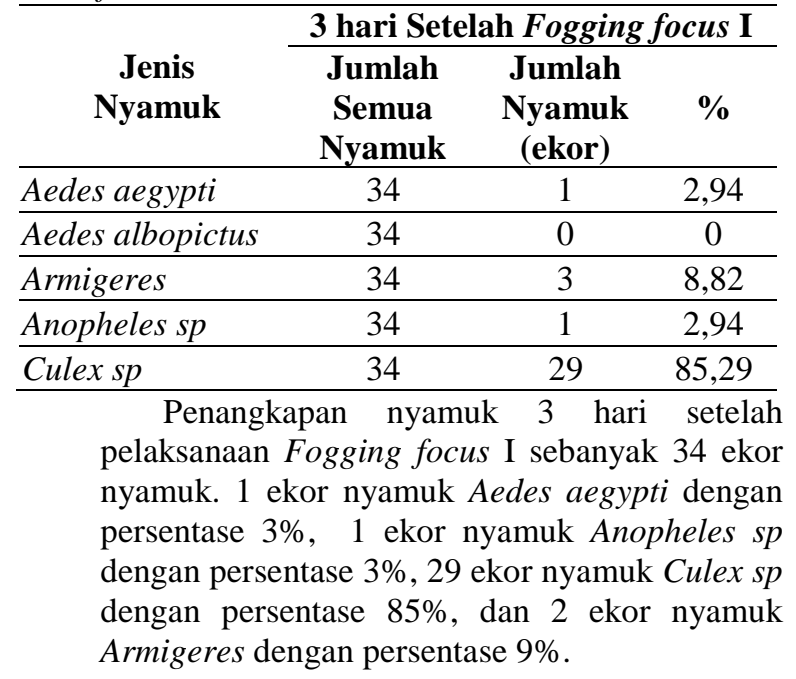

7. Penangkapan Nyamuk 3 hari Setelah fogging focus II

\begin{tabular}{lccc}
\hline \multirow{2}{*}{$\begin{array}{c}\text { Jenis } \\
\text { Nyamuk }\end{array}$} & \multicolumn{3}{c}{ 3 Hari Setelah Fogging focus } \\
& $\begin{array}{c}\text { Jumlah } \\
\text { Semua } \\
\text { Nyamuk }\end{array}$ & $\begin{array}{c}\text { Jumlah } \\
\text { Nyamuk } \\
\text { (ekor) }\end{array}$ & \% \\
\hline Aedes aegypti & 63 & 0 & 0 \\
\hline Aedes albopictus & 63 & 0 & 0 \\
\hline Armigeres & 63 & 2 & 3,17 \\
\hline Anopheles sp & 63 & 0 & 0 \\
\hline Culex sp & 63 & 61 & $\begin{array}{c}\text { J6,8 } \\
\text { (exyyy}\end{array}$ \\
\hline
\end{tabular}

Penangkapan nyamuk 3 hari setelah pelaksanaan Fogging focus II sebanyak 63 ekor nyamuk. 61 ekor nyamuk Culex sp dengan persentase 97\%, 2 ekor nyamuk Armigeres dengan persentase 3\%, Aedes aegypti 0\%, Aedes albopictus 0\% dan Anopheles sp 0\%.

8. Penangkapan Nyamuk 10 hari Setelah fogging focus II

\begin{tabular}{|c|c|c|c|}
\hline \multirow{2}{*}{$\begin{array}{c}\text { Jenis } \\
\text { Nyamuk }\end{array}$} & \multicolumn{3}{|c|}{$\begin{array}{c}10 \text { hari sebelum Fogging } \\
\text { focus II }\end{array}$} \\
\hline & $\begin{array}{c}\text { Jumlah } \\
\text { Semua } \\
\text { Nyamuk }\end{array}$ & $\begin{array}{c}\text { Jumlah } \\
\text { Nyamuk } \\
\text { (ekor) }\end{array}$ & $\%$ \\
\hline Aedes aegypti & 96 & 0 & 0 \\
\hline Aedes albopictus & 96 & 2 & 2,08 \\
\hline Armigeres & 96 & 4 & 4,16 \\
\hline Anopheles sp & 96 & 1 & 1,04 \\
\hline Culex sp & 96 & 89 & 92,7 \\
\hline
\end{tabular}

dengan persentase 2\%, 1 ekor nyamuk Anopheles sp dengan persentase 1\% , 89 ekor nyamuk Culex sp dengan persentase 93\%, 4 ekor nyamuk Armigeres dengan Persentase 4\% dan Aedes aegypti dengan persentase $0 \%$.

9. Penangkapan Nyamuk 17 hari Setelah fogging focus II

\begin{tabular}{|c|c|c|}
\hline \multirow[b]{2}{*}{$\begin{array}{c}\text { Jenis } \\
\text { Nyamuk }\end{array}$} & \multicolumn{2}{|c|}{17 hari Setelah Fogging focus II } \\
\hline & $\begin{array}{cc}\text { Jumlah } & \text { Jumlah } \\
\text { Semua } & \text { Nyamuk } \\
\text { Nyamuk } & \text { (ekor) } \\
\end{array}$ & $\%$ \\
\hline Aedes aegypti & $112 \quad 0$ & 0 \\
\hline Aedes albopictus & 112 & 1,78 \\
\hline Armigeres & 112 & 1,78 \\
\hline Anopheles sp & 112 & 0,89 \\
\hline Culex sp & $\begin{array}{ll}112 & 107 \\
\end{array}$ & 95,53 \\
\hline $\begin{array}{l}\text { Penang } \\
\text { pelaksanaan } \\
\text { nyamuk. 2 } \\
\text { dengan pe } \\
\text { Anopheles } \\
\text { nyamuk cul } \\
\text { nyamuk Ar } \\
\text { Aedes aegyl }\end{array}$ & $\begin{array}{l}\text { xapan nyamuk } 17 \\
\text { Fogging focus II sebany } \\
\text { ekor nyamuk Aedes } \\
\text { rsentase } 2 \%, 1 \text { eko } \\
p \text { dengan persentase } 1 \% \\
\text { ex sp dengan persentase } \\
\text { nigeres dengan persenta } \\
\text { ti dengan persentase } 0 \% \text {. }\end{array}$ & $\begin{array}{r}\text { setelah } \\
112 \text { ekor } \\
\text { lbopictus } \\
\text { nyamuk } \\
107 \text { ekor } \\
\%, 2 \text { ekor } \\
2 \% \text { dan }\end{array}$ \\
\hline
\end{tabular}

10. Grafik Main Plot

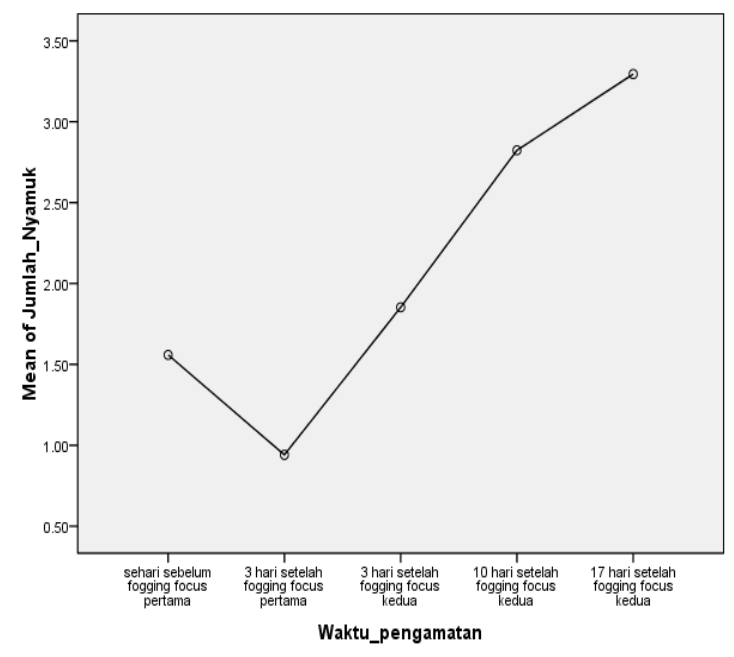

Penangkapan nyamuk yang di lakukan dengan mengikuti perkembangan umur nyamuk dimulai dari sebelum pelaksanaan fogging focus I sampai dengan 17 hari setelah pelaksanaan fogging focus II mengalami fluktuasi, mengalami penurunan jumlah nyamuk terlebih dahulu pada penangkapan 3 hari setelah pelaksanaan fogging focus I dan cenderung meningkat secara signifikan secara terus menerus setelah 3 hari pelaksanaan fogging focus ke II. Hal ini menunjukan bahwa fogging focus bisa di katakan tidak mempengaruhi densitas nyamuk dewasa, fogging focus hanya efektif setelah 3 hari pada siklus fogging focus ke II dan pada hari ke 17 setelah pelaksanaan fogging focus ke II mengalami penurunan 
karena terdapat indikator secara tidak langsung terhadap densitas nyamuk yaitu adanya PSN (Pemberantasan Sarang Nyamuk).

11. Deskripsi Pelaksanaan fogging focus

Pada pelaksanaan fogging focus konsentrasi insektisida yang digunakan sudah sesuai dengan yang tertera pada label pestisida yang digunakan yaitu 0,5 per 10 liter solar. Jenis insektisda yang digunakan untuk fogging yaitu dengan bahan sipermetrin dari golongan peritroid. Fogging dilakukan 2 siklus dengan interval waktu kurang 7 hari hanya interval 5 hari. Menurut Direktorat Jenderal P3M (1981:9) penanggulangan focus Demam Berdarah Dengue bahwa fogging dilakukan dengan frekuensi 2 siklus dalam interval 7 hari. Pelaksanaan fogging I tidak sesuai dilakukan pada pukul 11.00 WIB. Saatsaat pelaksanaan ini adalah berdasarkan pertimbangan kecepatan angin dan suhu udara pada saat tersebut pada umumnya rendah. Pengasapan diluar ruangan pada waktu tengah hari atau pada suhu tinggi akan sia-sia karena asap akan menyebar keatas tidak kesamping sehingga dikatakan tidak maksimal oleh sebab itu maka kegiatan fogging focus dilakukan pada pagi hari atau sore hari.

Fogging dilakukan oleh petgas fogging di mulai dari dalam ruangan yang paling belakang, jendela dan pintu di tutup kecuali pintu depan sebagai keluar masuk petugas. fogging diluar ruangan hanya sebagian halaman yang di fogging. sedangkan untuk keseluruhan ruangan yang ada di luar tidak fogging semua. pada saat fogging masyarakat berada di luar.

Kompetensi petugas fogging berjumlah 7 orang yang meliputi 1 orang supervisor dan 6 orang petugas fogging.Petugas pelaksana mendapatkan pelatihan fogging secara berkala setiap 2 tahun sekali. Setiap selesai kegiatan fogging sampai saat ini belum pernah di lakukan evaluasi kepadatan vektor.

\section{Bivariate}

12. Uji Statistik

\begin{tabular}{clrl}
\hline Variabel & \multicolumn{1}{c}{ F } & P & Kesimpulan \\
\hline Jumlah Nyamuk & $\begin{array}{l}2.46 \\
0\end{array}$ & .047 & Ho di tolak \\
\hline
\end{tabular}

Karena Ho di tolak maka uji lanjut LSD, hasilnya sebagai berikut :

\begin{tabular}{|c|c|c|}
\hline Pengamatan & $\begin{array}{l}\text { Beda } \\
\text { Mean }\end{array}$ & Kesimpulan \\
\hline $\begin{aligned} \text { Sebelum } & 3 \text { hari } \\
\text { fogging I setelah } & \\
& \text { fogging I }\end{aligned}$ & .61765 & $\begin{array}{l}.474 \text { Tidak ada beda Sebelum } \\
\text { fogging I dengan } 3 \text { hari } \\
\text { setelah fogging II }\end{array}$ \\
\hline
\end{tabular}

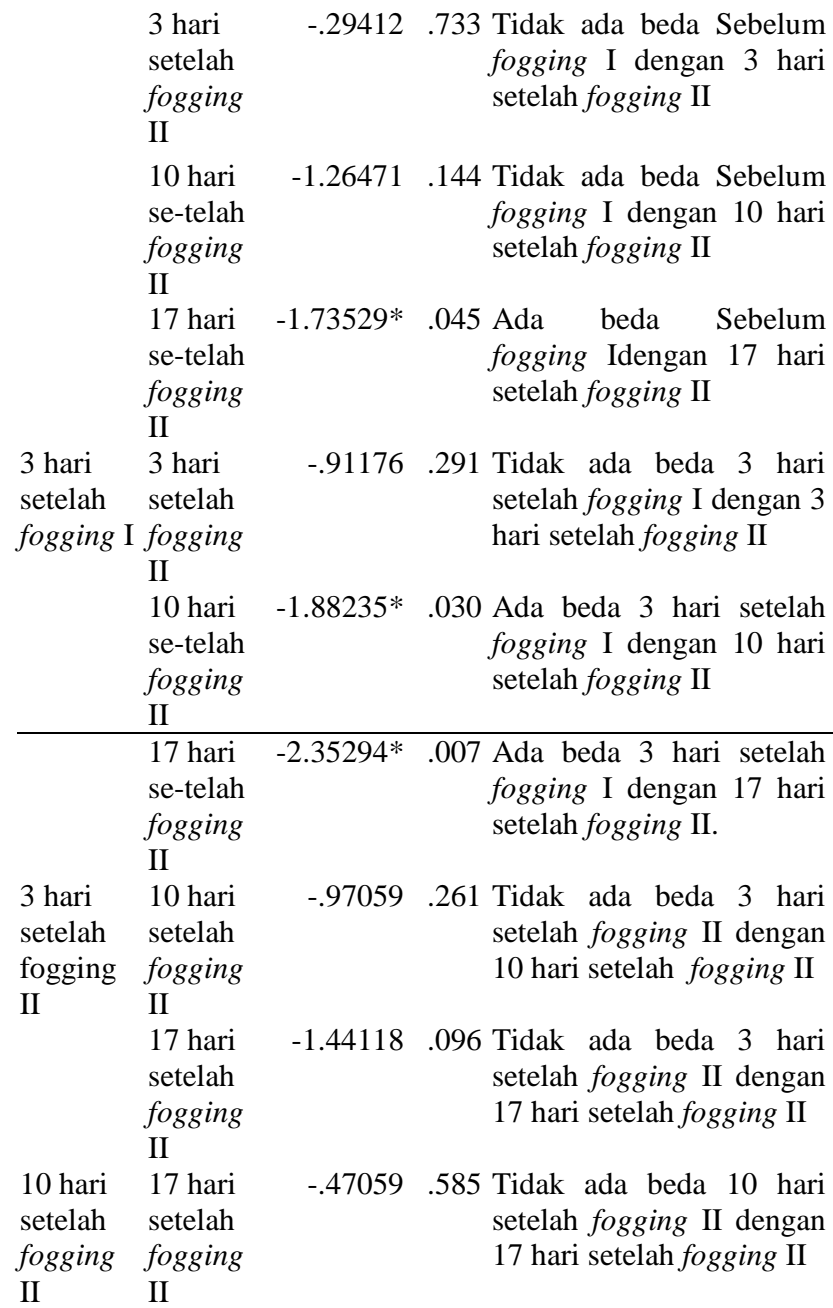

a. Sebelum Fogging Focus I dengan 3 Hari Setelah Fogging Focus I.

Hasil analisis bivariate mengenai hubungan sebelum fogging focus I dengan 3 Hari Setelah fogging focus I. Hasil analisis statistik antara sebelum fogging focus I dengan 3 hari setelah fogging focus I menunjukkan beda mean $=.61765$ dengan $\mathrm{p}$ $=0,474 \quad(\mathrm{p}>0,05)$ hasil tersebut tidak signifikan, artinya tidak ada beda densitas nyamuk sebelum fogging I dengan 3 hari setelah fogging I.

b. Sebelum fogging focus I dengan 3 Hari Setelah Fogging focus II

Hasil analisis statistik antara sebelum fogging focus I dengan 3 hari setelah fogging focus II menunjukkan beda mean = -.29412 dengan $\mathrm{p}=0,733 \quad(\mathrm{p}>0,05)$, artinya tidak ada beda densitas nyamuk sebelum fogging I dengan 3 hari setelah fogging II. Sehingga dapat diartikan bahwa nyamuk dewasa tidak mati semua pada saat 3 hari setelah fogging focus II karena adanya resistensi, dalam interval 5 hari telur tersebut masih dalam bentuk larva sehingga tidak terkena fogging dan pada 3 hari fogging focus II setelah pengamatan larva 
tersebut menjadi nyamuk dewasa 7-10 hari sehingga dilakukan penangkapan nyamuk dewasa 3 hari setelah fogging focus II densitasnya mengalami peningkatan. 3 hari setelah fogging focus II mengalami peningkatan jumlah nyamuk hal ini berbanding terbalik dengan fogging focus secara teoristis. Fogging focus secara teoritis dilakukan dengan siklus dua kali, fogging I dilakukan untuk membunuh nyamuk dewasa, fogging II dilaksanakan 7 hari setelah fogging I. Hal ini dimaksudkan bahwa jentik-jentik nyamuk sebelum fogging I sudah siap menjadi nyamuk dewasa. Selain itu efek fogging hanya akan membunuh nyamuk dewasa saja. Pada saat yang sama sekitar 200-400 jentik-jentik nyamuk akan siap menggantikan induknya yang terbunuh hanya dalam waktu seminggu saja (Dirjen PPBB, Depkes RI, 2008). Maka ditegaskan setelah 7 hari jentik-jentik tersebut telah menjadi nyamuk dewasa karna siklus perkembangbiakan dari jentik ke nyamuk dewasa adalah kurang lebih 7 hari. Dengan demikian setelah fogging II tidak ada lagi nyamuk dewasa yang bertelur dan menjadi jentik. Maka dari itu hal yang mempengaruhi densitas nyamuk adalah dari telur dan larva yang tidak terkena fogging.

c. Sebelum Fogging focus I dengan 10 Hari Setelah Fogging focus II

Hasil analisis statistik antara sebelum fogging focus I dengan 10 hari setelah fogging focus II menunjukkan beda mean = -1.26471 dengan $\mathrm{p}=0,114(\mathrm{p}>0,05)$, artinya tidak ada beda densitas nyamuk sebelum fogging I dengan 10 hari setelah fogging II. Hasil tersebut menunjukkan bahwa nyamuk masih ada bahkan lebih banyak lagi dari sebelumnya hal ini terjadi karena nyamuk dewasa tidak semua mati pada saat di fogging I dan II atau mengalami resistensi buktinya sampai 10 hari setelah fogging focus II nyamuk di dapatkan lebih banyak dari sebelumnya. Kemungkinan yang II bahwa telur yang masih ada saat sebelum fogging focus I atau 3 hari setelah fogging focus I belum menetas semua dan penetasan telur yang dalam waktu berbeda ketika dilakukan fogging focus II. Dalam penelusuran dibuktikan dari penelitian Isna Fadlilah (2016) ditemukan 914 larva pupa 133 dan nyamuk dewasa 73 dalam interval waktu 2 minggu, hal ini berarti bahwa telur itu tidak menetas secara bersama-sama. Kemungkinan yang ketiga adalah dari 2 hal tersebut terjadi secara bersama-sama, yaitu bahwa tidak semua nyamuk dewasa mati saat fogging focus I maupun fogging focus yang II, dan tidak semua telur menetas dalam waktu yang sama. Jika kemungkinan ini terjadi, berarti 10 hari setelah fogging yang II perlu di lakukan fogging lagi karena 2 kali fogging saja tidak cukup untuk menurunkan densitas nyamuk. Akan tetapi, hal ini dapat mengakibatkan terjadinya resistensi terhadap nyamuk.

d. Sebelum Fogging focus I dengan 17 Hari Setelah Fogging focus II

Hasil analisis statistik antara sebelum fogging focus I dengan 17 hari setelah fogging focus II menunjukkan beda mean = $-1.73529 *$ dengan $\mathrm{p}=0,045(\mathrm{p}<0,05)$, artinya ada beda densitas nyamuk sebelum fogging Idengan 17 hari setelah fogging II. Terjadi penurunan pada saat 17 hari setelah fogging focus II jika dibandingkan dengan sebelum fogging focus I. Hal tersebut dapat terjadi karena adanya Pemberantasan Sarang Nyamuk (PSN) saat sehari sebelum pengamatan.Hal tersebut membuktikan bahwa kegiatan PSN memberikan dampak secara lagsung terhadap larva, namun juga memberikan dampak secara tidak langsung terhadap densitas nyamuk.

e. 3 Hari Setelah Fogging focus I dengan 3 Hari Setelah Fogging focus II

Hasil analisis statistik antara 3 hari setelah fogging focus I dengan 3 hari setelah fogging focus II menunjukkan beda mean = -.91176 dengan $\mathrm{p}=0,291$ ( $\mathrm{p}>0,05)$, artinya tidak ada beda densitas nyamuk 3 hari setelah fogging I dengan 3 hari setelah fogging II. Hal tersebut menunjukkan bahwa 3 hari setelah fogging focus I dan 3 hari setelah fogging focus yang II hasilnya tidak ada beda bahkan terjadi peningkatan yang signifikan terhadap densitas nyamuk, hal ini menandakan fogging focus mulai tidak efektif.

f. 3 Hari Setelah Fogging focus I dengan 10 Hari Setelah Fogging focus II

Hasil analisis statistik antara 3 hari setelah fogging focus I dengan 10 hari setelah fogging focus II menunjukkan beda mean = -1.88235* dengan $\mathrm{p}=0,030 \quad(\mathrm{p}<0,05)$, artinya ada beda densitas nyamuk3 hari setelahfogging Idengan 10 hari setelah fogging II. Hal tersebut membuktikan bahwa densitas nyamuk pada saat 10 hari setelah fogging focus yang II lebih tinggi jika dibandingkan dengan 3 hari setelah fogging focus I. Artinya saat 10 hari setelah fogging focus yang II terjadi peningkatan densitas nyamuk yang signifikan, bahkan 
kondisinya lebih tinggi jika dibandingkan dengan sebelum fogging focus I atau kondisi awal sebelum dilakukan fogging focus. Hal tersebut membuktikan bahwa setelah 10 hari sudah tidak ada efek fogging focus.

g. 3 Hari Setelah Fogging focus I dengan 17 Hari Setelah Fogging focus II

Hasil analisis statistik antara 3 hari setelah fogging focus I dengan 17 hari setelah fogging focusII menunjukkan beda mean = 2.35294* dengan $\mathrm{p}=0,007 \quad(\mathrm{p}<0,05)$, artinya ada beda densitas nyamuk3 hari setelah fogging Idengan 17 hari setelah fogging II.17 hari setelah fogging focus II terjadi kenaikan yang tidak signifikan. Hal ini terjadi karena adanya PSN sehari sebelum pengamatan 17 hari setelah fogging focus II. Hal ini menunjukkan bahwa PSN memberikan dampak secara tidak langsung terhadap densitas nyamuk. Namun memberikan dampak secara langsung terhadap larva.

h. 3 Hari Setelah Fogging focus II Dengan 17 Hari Setelah Fogging focus II

Hasil analisis statistik antara 3 hari setelah fogging focus II dengan 17 hari setelah fogging focus II menunjukkan beda mean = -1.44118 dengan $\mathrm{p}=0,096$ ( $\mathrm{p}>0,05)$, artinya tidak ada beda densitas nyamuk 3 hari setelah fogging II dengan 17 hari setelah fogging II.

i. 10 Hari Setelah Fogging focus II dengan 17 Hari Setelah Fogging focus II

Hasil analisis statistik antara 10 hari setelah fogging focus II dengan 17 hari setelah fogging focus II menunjukkan beda mean = -.47059 dengan $p=0,585 \quad(p>0,05)$, artinya tidak ada beda densitas nyamuk 10 hari setelah fogging II dengan 17 hari setelah fogging II. Maka dapat fogging focus pada hari ke 10 setelah fogging focus ke dua sampai 17 hari setelah fogging focus II sudah tidak mempunyai efek apapun terhadap vektor nyamuk. Dan pestisida dapat mengalami penurunan kualitas karena adanya waktu lama paparan dengan lingkungan seperti kelembaban, suhu, intensitas cahaya dan kecepatan angin pada saat fogging focus dilakukan dan dapat mempengaruhi sifat efektivitas pestisida menjadi berkurang.

\section{SIMPULAN DAN SARAN}

\section{Simpulan}

Hasil penelitian menunjukan dengan analisis uji One Way Anova yaitu ada beda densitas nyamuk sebelum dan setelah pelaksanaan fogging focus.

Hasil analisis dilanjutkan ke uji lanjut LSD yang menunjukan bahwa sebelum fogging I ada beda dengan 17 hari setelah fogging II (p 0,045). Dan sebelum fogging I tidak ada beda dengan 3 hari setelah fogging I (p 0,474), 3 hari setelah fogging II (p 0,733), 10 hari setelah fogging II (p 0,144). Sedangkan pada 3 hari setelah fogging I ada beda dengan 10 hari setelah fogging II (p 0,030), 17 hari setelah fogging II (p 0,007) dan tidak ada beda dengan 3 hari setelah fogging II (p 0,291).Pada 3 hari setelah fogging II tidak ada beda dengan 10 hari setelah fogging II (p 0,261), 17 hari setelah fogging II (p 0,096) pada 10 hari setelah fogging II tidak ada beda dengan 17 hari setelah fogging II (p 0,585).

\section{Saran}

Peneliti menyarankan untuk penelitian selanjutnya dilakukan penelitian lebih lanjut melalui penelitian transovari dan bioassay karena bisa jadi densitas nyamuk tidak mengalami peningkatan lagi.

\section{UCAPAN TERIMA KASIH}

Terima kasih disampaikan kepada Desa Sidamulih Kecamatan Rawalo Kabupaten Banyumas dan Jurusan Kesehatan Lingkungan Politeknik Kesehatan Kemenkes Semarang, sehingga penelitian dapat terselesaikan.

\section{DAFTAR PUSTAKA}

Ambarwati, dkk., 2006. Fogging Sebagai Upaya Untuk Memberantas Nyamuk Penyebab Demam Berdarah di Dukuh Tuwak Desa Gonilan, Kartasura, Sukoharjo Tahun 2006. Skripsi. Surakarta : Universitas Muhammadiyah Surakarta, Fakultas Ilmu Kedokteran.

Aris, S. 2013. Malaria Pendekatan Mode Kausalitas. Yogyakarta : Nuha Medika

Cecep, DS. 2011. Vektor Penyakit Tropis. Yogyakarta : Gosyen Publishing.

Chadijah,Siti.,Rosmini,Halimuddin.Peningkatan Peran Serta Masyarakat dalam Pelaksanaan Pemberantasan Sarang Nyamuk DBD (PSN-DBD)di Dua Kelurahan di Kota Palu, Sulawesi Tengah. Media Litbang Kesehatan Vol. 21 (2). 2011.

Departemen Kesehatan RI. 1981. Petunjuk PelaksanaanPenanggulangan Focus Demam Berdarah. Jakarta : Depkes RI, Dirjen PP dan PL. 
Departemen Kesehatan RI. 1992. Petunjuk Teknis Pemberantasan Nyamuk Penular Penyakit Demam Berdarah Dengue. Jakarta : Depkes RI, Dirjen PPM dan PLP.

Departemen Kesehatan RI. 2008. Pencegahan dan Pemberantasan Demam Berdarah Dengue di Indonesia. Jakarta : Depkes RI, Dirjen PP dan PL.

Dinas Kesehatan Kabupaten Banyumas. 2015. Data Endemisitas DBD Kabupaten Banyumas Tahun 2014. Banyumas : Dinas Kesehatan Kabupaten Banyumas.

Dinas Kesehatan Kota Tegal, 2009, Profil Dinas Kesehatan Kota Tegal, Tegal : Dinas Kesehatan Kota Tegal.

Dinas Kesehatan Provinsi Jawa Tengah. Profil Kesehatan Provinsi Jawa Tengah Tahun 2014. Semarang. http://www.dinkes jateng prov.go.id. Diakses tanggal 11 Mei 2015

Direktorat Jenderal Pemberantasan Penyakit Menular dan Penyehatan Lingkungan (DitjenPPM\&PL) Departemen Kesehatan RI, 1992, Petunjuk Teknis Penyelidikan Epidemiologi,Penanggulangan Seperlunya dan Penyemprotan Massal dalam Pemberantasan Penyakit Demam Berdarah Dengue,.Jakarta: Depkes RI.

Direktorat Jenderal PPM dan PL. 2014.Pencegahan dan Pemberantasan Demam Berdarah Dengue di Indonesia, Jakarta:Ditjen PPM dan PL.

Fadlillah, I. 2016. Pengaruh Berbagai Jenis Atraktan pada Lethal Ovitrap Terhadap Nyamuk yang Terperangkap di Kelurahan Karangklesem Kecamatan Purwokerto Selatan Kabupaten Banyumas. 2016.

Genis, G. Apa yang Dokter Anda Tidak Katakan Tentang Demam Berdarah.Jakarta: PT. Mizan Publika.. 2007.

Harnowo. 2004. Evaluasi Pelaksanaan Fogging Focus Pengendalian Vektor Demam Berdarah Dengue di Kabupaten Kebumen Tahun 2004.

Ishak H. 2006. Pemetaan Distribusi Densitas Larva Aedes Aegypti Dan Pelaksanaan 3m Dengan Kejadian DBD Di Kelurahan Kalukuang Kecamatan Tallo Kota Makassar. Bagian kesehatan Lingkungan Fakultas Kesehatan Masyarakat Universitas Hasanuddin.
Kusriastuti. 2005. Kebijaksanaan Penanggungan DBD di Indonesia . JAKARTA: Depkes RI.

Nuanong,J.,Pornpimol,R.,Rognopast. 2007. Insecticide Resistance/Susceptibility Status in Ae.aegypti, and Ae.albopictus in Thailand during 2003-2005. Journal Economic Entomology. 100 (2)

Primal, S. 2010. Diagnosis Dini Penderita DBD Dewasa. Buletin Jendela Epidemiologi Volume 2.

Ratna, M. Panduan Lengkap Kesehatan : Mengenal, Mencegah dan Mengobati Penularan Penyakit dari Infeksi. Yogjakarta : Citra Pustaka. 2010.

Soegeng, S. 2006. Demam Berdarah Dengue edisi II. Surabaya : Airlangga University Press.

, 2008. Demam Berdarah Dengue edisi ketiga. Surabaya : Airlangga University Press.

Wikipedia. 2010. Anthocyanin. Available at: http://en.wikipedia.org/wiki/Anthocyanin/Ac cessed at 08/21 2010

World Health Organization. 2001. Panduan Lengkap Pencegahan \& Pengendalian Dengue \& DBD. Jakarta : Penerbit Buku Kedokteran EGC

World Health Organization, 2003. Pencegahan dan Penanggulangan Penyakit Demam Dengue dan Demam Berdarah Dengue.

World Health Organization, 2005. Dengue, Dengue Hemorrhagic Fever, and Dengue Shock Syndrome in the Context of the Integrated Management of Childhood Illness. World Health Organization.

WHO. 2006. Pesticides, and Their Aplication: for The Controll of Vectors, and Pests of Public Health Importance WHOPES/GCDD/2006.I

World Health Organization, 2009. Dengue and Dengue Hemorrhagic Fever. World Health Organization Media Centre.

World Health Organization Dengue. 2013Prevention and Control Regional Office for South East Asia, 2013. Dengue Status in South East Asia Region : An Epidemiological Perspective. WHO Fact Sheet No 117SEA/RC61/R5. 